\title{
8-4-2004
}

\section{The Stoic Theory of Implanted Preconceptions}

Matt Jackson-McCabe

Cleveland State University, m.jacksonmccabe@csuohio.edu

Follow this and additional works at: https://engagedscholarship.csuohio.edu/clrelst_facpub

Part of the Religious Thought, Theology and Philosophy of Religion Commons

How does access to this work benefit you? Let us know!

\section{Recommended Citation}

Jackson-McCabe, Matt. 2004. The stoic theory of implanted preconceptions. Phronesis: A Journal for Ancient Philosophy 49, no. 4: 323-347.

This Article is brought to you for free and open access by EngagedScholarship@CSU. It has been accepted for inclusion in Religious Studies Faculty Publications by an authorized administrator of EngagedScholarship@CSU. For more information, please contact library.es@csuohio.edu. 


\title{
The Stoic Theory of Implanted Preconceptions*
}

\author{
MATT JACKSON-MCCABE
}

\begin{abstract}
A number of late Stoic sources describe either ethical concepts or a supposed universal belief in gods as being innate in the human animal. Though Chrysippus

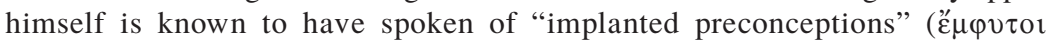
$\pi \rho \circ \lambda \dot{\eta} \psi \varepsilon 1 \varsigma)$ of good and bad, scholars have typically argued that the notion of innate concepts of any kind would have been entirely incompatible with his theory of knowledge. Both Epictetus' notion of innate concepts of good and bad and the references to an innate belief in gods by other philosophers of the Roman era are thus generally held to be later developments, probably owing to a PlatonistStoic syncretism. Review of the evidence, however, shows that Chrysippus, like Epictetus, held ethical concepts to represent a special category of conception in that their formation was guaranteed by oikeiosis. Unlike other concepts, that is, these represent a formal conceptualization of an innate tendency to distinguish between things fitting for one's constitution and things not fitting that all animals, according to the Stoics, bring to their empirical experiences. While the notion that human belief in gods is similarly innate does seem to have been a later development, it too was explained with reference to oikeiôsis rather than resulting from a simple "syncretism."
\end{abstract}

Chrysippus, Plutarch reports, claimed that his teaching concerning good and bad things was particularly compatible with "the implanted precon-

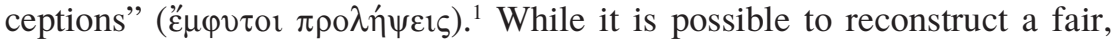
if imperfect picture of his teaching on the subject of good and bad, ${ }^{2}$ what exactly Chrysippus understood these implanted preconceptions to be is far from immediately obvious. Though he was later praised for having brought special clarity to the topic of preconception and conception,

\section{Accepted March 2004}

* The basic argument of this paper was first presented in Matt Jackson-McCabe, Logos and Law in the Letter of James (NovTSup 100, Leiden: Brill, 2001) 43-73. The present version would not have been developed without a generous grant from the Niagara University Research Council, for which I am most grateful.

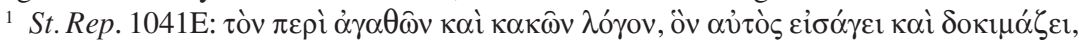

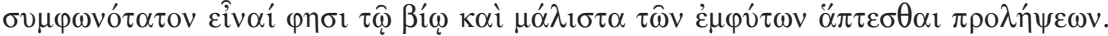

2 See, e.g., Josiah B. Gould, The Philosophy of Chrysippus (Albany: SUNY Press, 1970) 161-98. 
"articulating each one and assigning it to its place," preconceptions are mentioned in the extant fragments of Chrysippus' writings only two other times, while the specific term "implanted preconception" is not repeated at all, let alone explained. ${ }^{3}$

Equivalent terms are used, however, in the works of later Stoics. Epictetus similarly describes concepts of good and bad - as well as other ethical pairs like honorable and shameful, proper and improper, and more

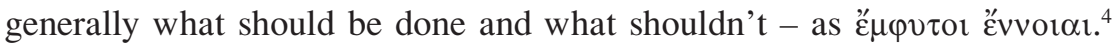
For Epictetus, who also calls such ethical notions $\pi \rho 0 \lambda \eta \dot{\psi} \psi \varepsilon 1 \varsigma$, the term "implanted concepts" clearly denotes innate concepts with which we are equipped from birth - in contrast, for example, with a concept like a right triangle, which is learned only through instruction. ${ }^{5}$ Epictetus thus considers such ethical concepts to be the common possession of all humanity, and disagreements about their concrete application, indeed, to be the ultimate origin of philosophy. ${ }^{6}$ Implanted preconceptions, as A. A. Long has well observed, thus lie at the very heart of Epictetus' philosophical and pedagogical interests. ${ }^{7}$

A number of philosophers of the Roman era, moreover, describe human belief in deity in the same way. Dio Chrysostom describes this common

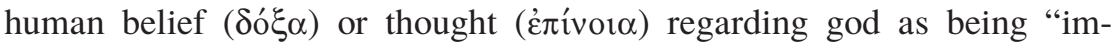
planted in every rational animal, coming about according to nature apart from a mortal teacher." ${ }^{\prime \prime}$ Seneca similarly asserts "that there is implanted in all people a belief in gods." Cicero's On the Nature of the Gods had

${ }^{3}$ SVF 2.105; 2.841. The quotation is from Plutarch, Comm. Not. 1059B (SVF 2.33), trans. after A. A. Long and D. N. Sedley, The Hellenistic Philosophers (Cambridge, etc.: Cambridge University Press, 1987) 1.244 (40G).

${ }^{4}$ Diss. 2.11.3.

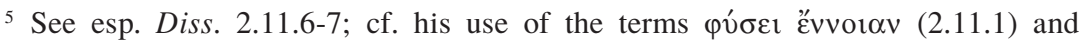

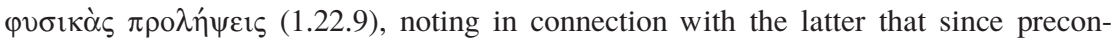
ceptions are natural by definition (see below), Epictetus must consider these to be natural in a more specialized sense.

${ }^{6}$ Diss. 1.22.1-8; cf. 2.11.8-14. While Epictetus speaks in the former passage simply of preconception, it is clear from the context that he has specifically ethical preconceptions in mind.

7 A. A. Long, Epictetus: A Stoic and Socratic Guide to Life (Oxford: Clarendon, 2002) 74-86, esp. 80, 82; cf. Iason Xenakis, Epictetus: Philosopher-Therapist (The Hague: Martinus Nijhoff, 1969) 59-64.

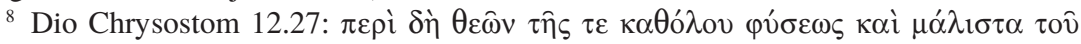

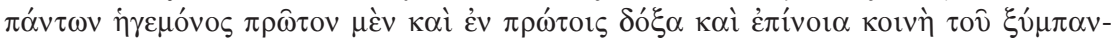

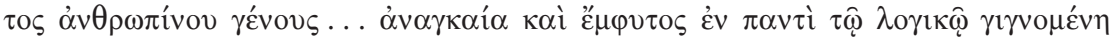

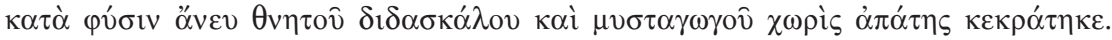

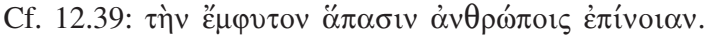

9 Seneca, Ep. 117.6: omnibus insita de dis opinio. 
in fact already placed such a view on the lips of its Stoic spokesperson, who characterizes the belief that gods exist as "innate in everyone," and "as if engraved in the soul." 10 The idea is also repeated by later Christians like Justin and Tertullian, the former of whom characterizes the term "god" as "a belief implanted in the nature of all human beings." 11

Adolf Bonhöffer, in his classic Epictet und die Stoa, understood Epictetus and such other later philosophers to be fundamentally consistent with Chrysippus on this issue, and thus indispensable for reconstructing the latter's treatment of preconception. ${ }^{12}$ Accordingly, he concluded that Chrysippus limited the term $\pi \rho{ }^{\prime} \lambda \eta \psi 1 \varsigma$ to concepts in the sphere of ethics and theology. Chrysippus, moreover, understood these concepts to be innate in the human animal - albeit only in "spermatic" form, given the Stoic view that the soul's commanding faculty, at birth, is like a blank slate (Aetius 4.11.1-4). ${ }^{13}$ Given their consequent universality, Bonhöffer

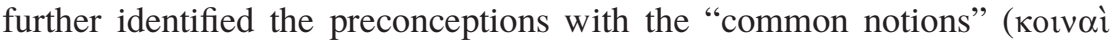
Ěvvolol). ${ }^{14}$

Though Bonhöffer's reconstruction found a few advocates, it is problematic in several important respects, as F. H. Sandbach clearly and succinctly demonstrated. ${ }^{15}$ First, despite the common tendency of scholars to do so, preconceptions should not be conflated with the Stoic common notions - a point that has been driven home by Robert B. Todd. ${ }^{16}$ Second,

${ }^{10}$ Nat. Deor. 2.12: omnibus enim innatum est et in animo quasi insculptum esse deos.

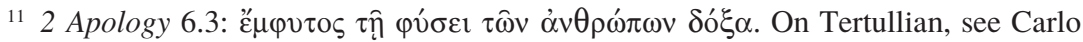
Tibiletti, "Tertulliano e la dottrina dell'anima 'naturaliter christiana'," Atti della Accademia delle scienze di Torino. Tomo 2: Classe di scienze morali storiche e filologiche 88 (1953-54) 84-117, esp. 109-15.

${ }^{12}$ Epictet und die Stoa: Untersuchungen zur Stoischen Philosophie (Stuttgart: Enke 1890; repr. Stuttgart-Bad Cannstatt: Friedrich Frommann Verlag [Günther Holzboog] 1968) $187-222$.

13 Ibid. 194f.

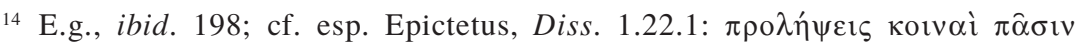

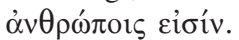

15 Bonhöffer is followed by Ernst Grumach, Physis und Agathon in der alten Stoa (Berlin, Zurich and Dublin: Weidmann, 1966 [1932]), esp. pp. 6-12 and 72-76; also Tibiletti, “Tertulliano," 104-108. For Sandbach's critique see "ENNOIA and ПРО $\Lambda$ H$\Psi I \Sigma$ in the Stoic Theory of Knowledge," CQ 24 (1930) 44-51; repr. with supplementary note in A. A. Long, Problems in Stoicism (London: Athlone Press, 1971) 22-37. References throughout this essay are to the reprinted version unless otherwise noted.

16 Ibid., 23-25; Sandbach deftly observes in any case that, if such an identification were made, then Bonhöffer's limitation of preconceptions to the sphere of religion and ethics would be impossible in light of Alexander's report that Chrysippus appealed to 
Stoics did not restrict the term $\pi \rho{ }^{\prime} \lambda \eta \psi 1 \varsigma$ to ethical and theological concepts. This much, indeed, is quite clear from Epictetus himself, who speaks elsewhere of preconceptions of the carpenter, the musician, and other artisans, as well as that of the philosopher. ${ }^{17}$ Finally, it seems quite clear that the Stoics held that some preconceptions, at least, were formed entirely as a result of empirical experience. One has difficulty imagining, for example, that Epictetus - let alone Chrysippus - would have argued that all human beings are born with an innate notion of a carpenter. ${ }^{18}$

In fact, most interpreters have argued that Chrysippus, at any rate, had no thought of innate concepts of any kind when he used the phrase "̌p $\mu v$ -

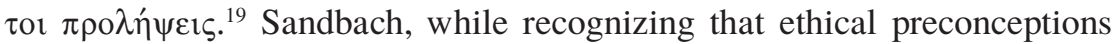
present a special problem, ultimately agrees: "what evidence we have on the origin of ideas of good does not in any way suggest that anything inborn played any part" in their case, either. ${ }^{20}$ If Sandbach already in 1930 could describe this as the "orthodox view" among scholars, his own analysis of the key evidence has come to be considered the classic refutation of Bonhöffer's contrary position. ${ }^{21}$ The teaching regarding innate precon-

common notions to confirm his teaching on mixture (p. 23). See further on the latter passage, and on this general issue, Robert B. Todd, "The Stoic Common Notions: A Re-examination and Reinterpretation," Symbolae Osloensis 48 (1973) 47-75, esp. 48-55.

17 Diss. 4.8.10; also 3.22.1 for a preconception of the work of a Cynic; cf. Sandbach, "ENNOIA," 26-27.

18 Cf. Sandbach, "ENNOIA," 25-26; see further on this point below. Bonhöffer could only account for these passages by suggesting that Epictetus was not using the term in its proper sense in these passages (Epictet und die Stoa, 197f). What Sandbach himself failed to see was that most of the problems in Bonhöffer's account stem from his

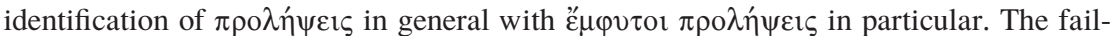
ure to recognize that the latter represent a special category of $\pi \rho{ }^{\prime} \lambda \eta \psi 1 \varsigma$ in effect led Bonhöffer to discount as technically improper usage any treatment of preconception

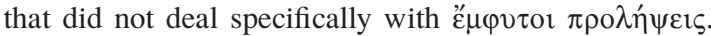

19 Eduard Zeller, The Stoics, Epicureans and Skeptics (trans. by Oswald J. Reichel; London: Longmans, Green and Co., 1880; rev. ed. New York: Russel and Russel, 1962) 81; Hans von Arnim, "Chrysippos," RCA 3 (1899) cols. 2507-8; Émile Bréhier, Chrysippe et L'Ancien Stö̈cisme (Paris: Presses Universitaires de France, 1951) 66f; Gould, The Philosophy of Chrysippus, 64-65, 200, 203.

${ }^{20}$ Sandbach, "ENNOIA," 28. The evidence in question is Cicero, Fin. 3.33 and Seneca Ep. 120.4ff, on which see further below.

21 J. M. Rist, Stoic Philosophy (Cambridge, etc.: Cambridge University Press, 1969; repr. 1990) 134 with nn. 3-4; Long, Epictetus, 96. There have been dissenting voices: see Gerard Watson, The Stoic Theory of Knowledge (Belfast: Queen's University, 1966) 24, who describes preconceptions as innate "dispositions to the formation of certain ideas," and continues to identify them further with the "common conceptions"; 
ceptions by Epictetus, Cicero and others is thus generally held to be a later development, resulting either from Platonist influence ${ }^{22}$ or, as recently suggested regarding Epictetus, from an interest in countering skeptical challenges to Stoicism. ${ }^{23}$

In what follows I will argue that Sandbach's essay, while providing a necessary corrective to Bonhöffer's account of Stoic preconception in several important respects, is problematic precisely on this issue of the origin of ethical preconceptions. A reconsideration of the evidence will show

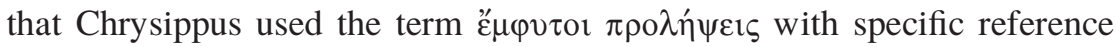
to preconceptions of the ethical sphere whose formation is guaranteed by oikeiôsis, and which in this sense represent a type of inborn knowledge. After reviewing the state of the question in more detail (Section II), the key evidence offered by Sandbach will be re-examined in order to show that it actually supports the thesis that ethical preconceptions were understood to be, at least in inchoate form, innate in the human animal (Section III). While Epictetus thus appears to be generally consistent with Chrysippus on this point, the idea of an implanted belief in gods does seem to have been a later development. Even here, however, the innovation seems to have been built primarily on the same genuinely Stoic foundation of oikeiôsis, not simply the result of a Platonist-Stoic syncretism (Section IV).

While reporting that Chrysippus, in the first book of his On Reason, had identified sensation and preconception as the criteria of truth, Diogenes

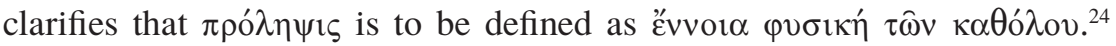

also Max Pohlenz, Grundfragen der stoischen Philosophie (Abhandlungen der Gesellschaft der Wissenschaften zu Göttingen 3/26; Göttingen: Vandenhoeck \& Ruprecht, 1940; repr. in Stoicism, [ed. Leonardo Tarán; Greek \& Roman Philosophy 38; New York \& London: Garland, 1987]) 82-103, on which see further below. Oddly, however, while both of these works cite Sandbach, neither directly refutes his argument.

${ }^{22}$ E.g., Sandbach, "ENNOIA," 29f.

${ }^{23}$ Robert F. Dobbin, Epictetus: Discourses Book I. Translated with an Introduction and Commentary (Oxford: Clarendon, 1998) 188. Long allows for the possibility of both Platonist and skeptical factors in the case of Epictetus (Epictetus, 83f, 96).

${ }^{24}$ Diog. L. 7.54. Diogenes seems to suggest that this definition also comes from Chrysippus' On Reason, but this is not entirely clear. The passage in any case strongly recalls Alexander's report that Chrysippus elsewhere identified as a criterion of truth

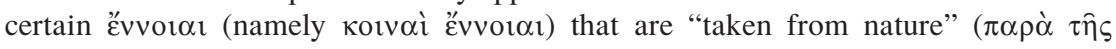


The definition is difficult, but seems in any event to identify preconception (i) as a form of conception ( $\varepsilon^{\prime} v v_{0} \alpha$ ) that is (ii) naturally acquired, and whose content is (iii) rather general, which is to say neither precisely nor adequately defined. ${ }^{25}$ The first two features, at least, are also clearly reflected in Aetius' report of the basic outlines of Stoic teaching on conception and preconception.

When a man is born, the Stoics say, he has the commanding-part of his soul like a sheet of paper ready for writing upon. On this he inscribes each one of his conceptions. The first method of inscription is through the senses. For by perceiving something, e.g. white, they have a memory of it when it has departed. And when many memories of a similar kind have occurred, we then say we have experience. Some conceptions arise naturally in the aforesaid ways and undesignedly, others through our own instruction and attention. The latter are called "conceptions' only, the former are called 'preconceptions' as well. Reason, for which we are called rational, is said to be completed from our preconceptions during our first seven years. ${ }^{26}$

The term Ëvvol $\alpha$ was used by the Stoics in two different senses: both as the genus of which $\pi \rho{ }^{\prime} \lambda \eta \psi 1 \varsigma$ is a species, and as a particular species of conception that contrasts with preconception in that it is acquired by conscious intellectual effort. ${ }^{27}$ The distinguishing feature of preconception, on the other hand, is thus its natural origin. In short, in the words of Chry-

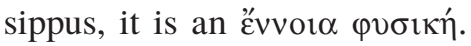

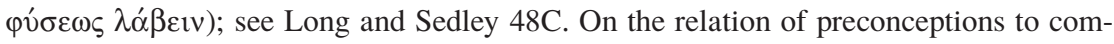
mon conceptions, and on this passage in particular, see above note 16 .

${ }^{25}$ Hicks (LCL) renders the phrase "a general notion which comes by the gift of nature." Cf. Sandbach, "ENNOIA," 25 and 35 n. 12, where it is rendered "natural conception of the general characteristics of a thing"; cf. Pohlenz, Grundfragen, 84; Bonhöffer, Epictet und die Stoa, 203-4.

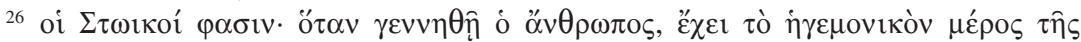

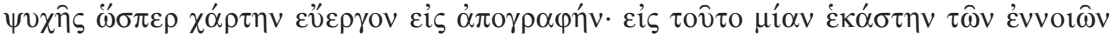

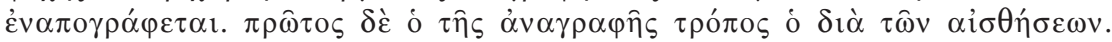

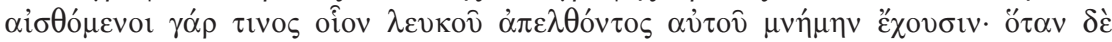

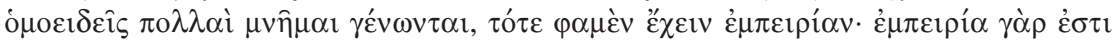

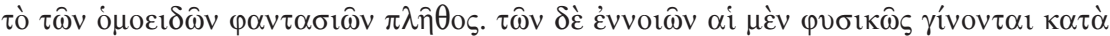

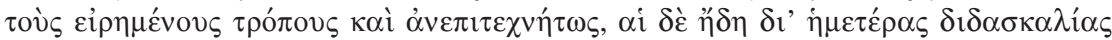

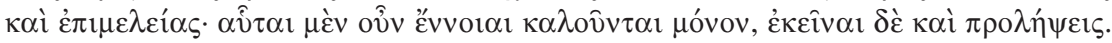

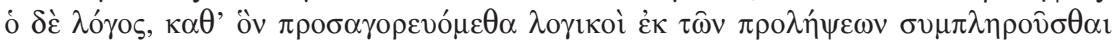

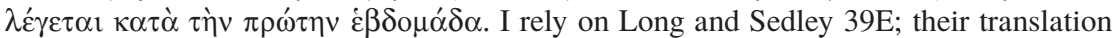
is apparently based on Sandbach, "ENNOIA," $25 \mathrm{f}$.

27 Cf. Pohlenz's distinction between "Ennoia im engeren Sinne" and as "Oberbegriff"' (Grundfragen, 84). 
The crucial question is how this natural acquisition is understood to take place. At least one sense is clear enough from Aetius' own report: preconceptions result from the natural tendency of the commanding faculty to organize sensual experience into abstract concepts. ${ }^{28}$ As this passage itself indicates, however, empirical experience was not understood to be the sole means of acquiring preconceptions. Both Aetius' use of the plural "aforesaid ways" and his labeling of direct experience as the "first" such way suggest that he has not provided a complete list of the natural means of acquiring preconceptions. It has long been suggested, then, that a fuller list can be found in Diog. L. 7.52-53. ${ }^{29}$

Of things conceived, some have been conceived by direct experience [ $\kappa \alpha \tau \grave{\alpha}$ $\pi \varepsilon p i \pi \tau \omega \sigma \mathrm{v}]$, some by resemblance, some by analogy, some by transposition, some by composition, some by contrariety. [A brief explanation of each process follows]... and some things are conceived by inference, like propositions and

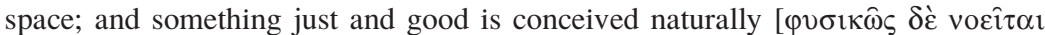

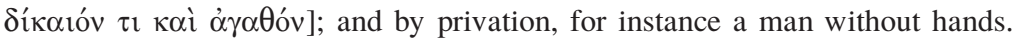

It is clear in any case from Diogenes' subsequent clarification that $\tau \grave{\alpha} \kappa \alpha \tau \grave{\alpha}$ $\pi \varepsilon p i ́ \pi \tau \omega \sigma v$ which head his list correspond to the conceptions acquired $\delta i \grave{\alpha}$

28 This begins to occur well before one is properly rational, and thus capable of forming Évvoial in the strict sense at all. As Aetius reports, the logos - which Chrysippus defined as "a collection of certain conceptions and preconceptions" (SVF

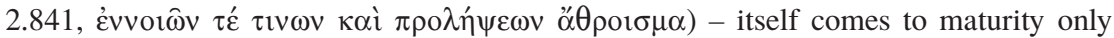
when a sufficient number of preconceptions have been formed. See further Brad Inwood, Ethics and Human Action in Early Stoicism (Oxford: Clarendon, 1985) 72-74.

29 This was accepted already by Bonhöffer, Epictet und die Stoa, 195, who credits the observation to Zeller; cf. Stoics, Epicureans and Skeptics, 79-80. Cf. Sandbach, "ENNOIA," 26, whose translation of the passage I give in a slightly altered form; also Pohlenz, Grundfragen, 82f; Todd, "Stoic Common Notions," 52f. This view still makes the best sense of the text, despite Sandbach's subsequent retraction (Aristotle and the Stoics [Cambridge Philological Society Sup. 10; Cambridge: University Press, 1985] 80 n. 118), which was inspired by Sedley, and which Long and Sedley thus endorse

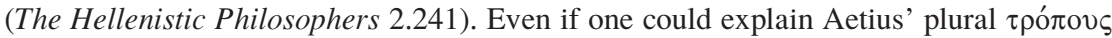
entirely with reference to the description of the processes involved in acquisition $\delta i \dot{\alpha}$ $\tau \hat{\omega} v \alpha i \sigma \theta \dot{\eta} \sigma \varepsilon \omega v$, this doesn't explain the introduction of the latter as $\pi \rho \hat{\omega} \tau o \varsigma \dot{o} \tau \hat{\eta} \varsigma$

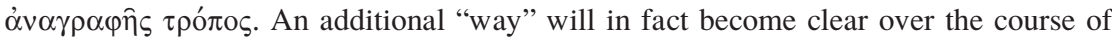
this essay. Finally, I find Long and Sedley's objection that "much of [this passage] does not fit the scope of "Evvoral" somewhat mystifying (The Hellenistic Philosophers 2.241). All of the examples given by Diogenes - with the possible exception of those acquired $\kappa \alpha \tau \grave{\alpha} \mu \varepsilon \tau \dot{\alpha} \beta \alpha \sigma \mathrm{v}$ - are in fact easily imagined as occurring "naturally" apart from the sort of intellectual effort required for conception in the strict sense. 
$\tau \hat{\omega} v \alpha i \sigma \theta \dot{\eta} \sigma \varepsilon \omega v$ in the account of Aetius. ${ }^{30}$ These, at least, are thus preconceptions. Moreover, since the concepts of "something just and good" are said to be acquired "naturally," these must also be considered preconceptions. If this much is true, it is quite striking that Diogenes singles out only the latter as being acquired naturally given that preconceptions by definition are distinguished by their natural origin. The implication is that notions of "something just and good" are understood to arise espe-

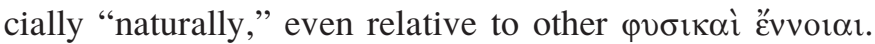

It is at this point that Chrysippus' description of ethical notions as "̌ $\mu \varphi v-$

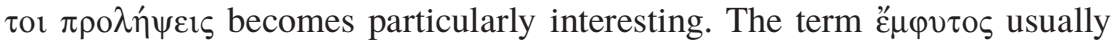
has the connotation "innate," though it is not always used in this way. ${ }^{31}$ What does it mean in this instance? Is the use of this term to describe ethical preconceptions in particular related to the especially "natural" origin of the latter indicated by Diogenes Laertius? Recognizing that the accounts of Aetius and Diogenes Laertius leave room for doubt as to whether ethical concepts, at least, might involve "something besides the winning of an idea from the material provided by the senses," Sandbach nonetheless finds in favor of "the orthodox view" that such an interpretation would be "contrary to all the other evidence, and in particular inconsistent with the image of the soul at birth as a sheet of paper ready to be inscribed with conceptions." ${ }^{32}$ Citing Cicero, Fin. 3.33 and Seneca's Epistle 120, he concluded that "what evidence we have on the origin of ideas of good does not in any way suggest that anything inborn played any part." 33 These passages agree, rather, that "the good" is conceived by means of analogy. In fact, Sandbach argued, the Cicero passage also "supplies the clue" for properly interpreting Diogenes Laertius' use of $\varphi v \sigma i \kappa \hat{s} s$ to characterize its acquisition:

Now notions of things are produced in the mind when something has become known either by experience or combination of ideas or analogy or logical inference. The fourth and last method in this list is the one that has given us the conception of the Good. The mind ascends by inference from the things in accordance with nature till finally it arrives at the notion of the Good. ${ }^{34}$

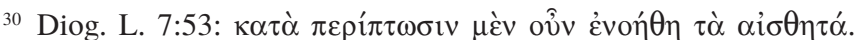

31 So rightly Sandbach ("ENNOIA," 28) against Bonhöffer (Epictet und die Stoa, 192f) - who himself, despite his insistence in this work, argues elsewhere that the term " $\mu \varphi v \tau o \varsigma$ does not mean "innate" when it is used in the New Testament Letter of James (Epiktet und das Neue Testament [RGVV 10; Gießen: Töpelmann, 1911] 97).

32 Sandbach, "ENNOIA," 28.

${ }_{33}$ Ibid.

${ }^{34}$ Cicero, Fin. 3.33, trans. after Rackham (LCL); cf. Sandbach, "ENNOIA," 29. 
Sandbach initially took this to mean that "We recognize the good through the force of its own nature." He later revised this interpretation so that "the nature referred to... must be that of the man who forms the concept, not that of the concept itself." In any event, he concluded, it has nothing whatsoever to do with innate concepts. ${ }^{35}$

Despite his own arguments, however, Sandbach ultimately confessed that he found it "difficult to feel confident that Chrysippus did not mean

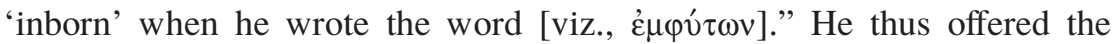
deeply unsatisfying suggestion that this usage - by a philosopher especially known for his clarity in elucidating the matter of preconception may have been "a temporary aberration." ${ }^{36}$ Sandbach's own reconstruction of the origin of the concept of the good, moreover, is hardly decisive. Bonhöffer had suggested that there was an important difference between Diog. L. 7.53 and Fin. 3.33: while the former passage was concerned with the origin of a hazy $\pi \rho{ }^{\prime} \lambda \eta \psi 1 \varsigma$ of something good, the latter dealt with an Évvora (in the strict sense) of the Good. ${ }^{37}$ If this is the case, Cicero's comments regarding analogy are not immediately relevant to the origin of the preconception. Sandbach - problematically (see below) - discounted this interpretation as "unconvincing in itself," and in any case "impossible" given Seneca's explicit interest in the initial occurrence of the concept in Epistle $120 .{ }^{38} \mathrm{He}$ could not himself in any case offer a definitive explanation of Diogenes' wording, and was still struggling with this passage when his article was reprinted forty years later. ${ }^{39}$ He relegated to his endnotes, moreover, mention of Seneca's potentially crucial point that, while knowledge of the good is arrived at by means of analogy, Nature herself has provided the "seeds" of that knowledge. The possibility that something innate is meant here is again quickly dismissed, with these "seeds" being interpreted, rather weakly, as the empirical data that give rise to the concept. ${ }^{40}$

Between the initial publication of Sandbach's article in 1930 and its reprinting in 1971, Max Pohlenz opened up a more promising line of inter-

35 Ibid., 29 and 33.

36 Sandbach, "ENNOIA," 28.

37 Epictet und die Stoa, 214-16.

38 Sandbach, "ENNOIA," 29. The stated topic of this epistle is "how a concept of the good and the honorable first comes to us" (120.3: quomodo ad nos prima boni honestique notitia pervenit).

39 See his comments in "ENNOIA," 33-34.

40 Ibid., 36 n. 23: "The 'semina' seem to be the facts observed." See further on this below. 
pretation in his Grundfragen der stoischen Philosophie. He drew attention to the following passage from Plutarch, in which the Stoics are criticized for their supposed contradiction of "common conceptions":

and this too in matters concerning good things and evil and objects of choice and avoidance and things congenial and repugnant, the clarity of which ought to be more manifest than that of things hot and cold and white and black, since the mental images of these are incidental to the sense-perceptions entering from without whereas the former are generated intrinsically from the principles within us. ${ }^{41}$

Here ethically-oriented concepts are said to arise directly $\dot{\varepsilon} \kappa \tau \hat{\omega} v \dot{\alpha} \rho \chi \hat{\omega} v$ of the human individual, and are on this basis explicitly distinguished from those originating from empirical experience. The use of the term

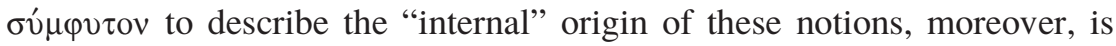

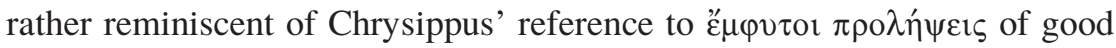
and bad. ${ }^{42}$

Sandbach, in a footnote, had pointed out that this passage "may perhaps be relevant" to the issue, but confessed to uncertainty regarding its meaning. ${ }^{43}$ Though Sandbach doubted "whether Plutarch is here confuting the Stoics out of their own mouths or not," the theoretical basis for the distinction drawn here, as Pohlenz recognized, is the Stoic doctrine of oikeiôsis. ${ }^{44}$ The Stoics argued that the first sensation that any animal experiences is one of self-awareness. ${ }^{45}$ Its first impulse, moreover,

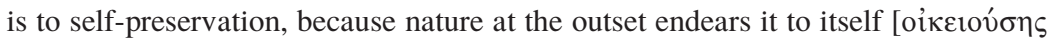

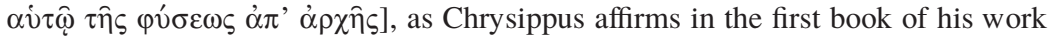
On Ends: his words are, 'The dearest thing to every animal is its own constitution and its consciousness thereof'; for it was not likely that nature should estrange the living thing from itself or that she should leave the creature she has made without either estrangement from or affection for its own constitution [ $\mu \eta^{\prime} \tau$ '

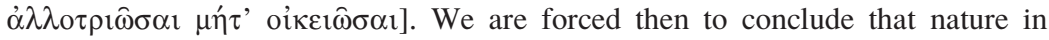
constituting the animal made it near and dear to itself; for so it comes to repel all that is injurious and give free access to all that is serviceable or akin to it. ${ }^{46}$

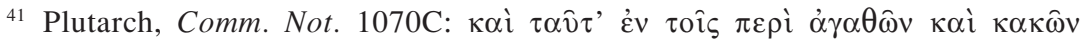

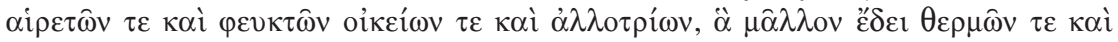

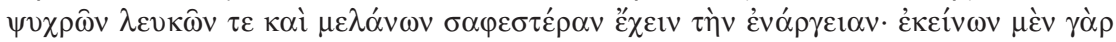

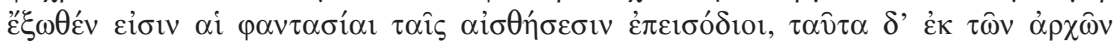

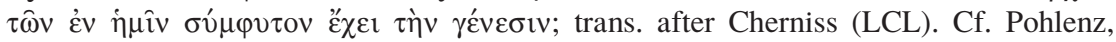
Grundfragen, 89.

42 Cf. Pohlenz, Grundfragen, 93.

43 Sandbach, "ENNOIA," 36 n. 24.

${ }^{44}$ Ibid.; cf. Pohlenz, Grundfragen, 89-93.

45 Long and Sedley 57C.

46 Diog. L. 7.85; trans. after Hicks (LCL). 
In a nutshell, the Stoics argued that the primary drive of all animals (including humans) is that toward the preservation of self. A providential Nature, moreover, endows all animals with both an awareness of their own constitution and a natural tendency to evaluate their experience subjectively, distinguishing those things that are helpful to their constitution from those that are harmful. ${ }^{47}$ The categories Plutarch lists as having been generated directly $\dot{\varepsilon} \kappa \tau \hat{\omega} v \dot{\alpha} \rho \chi \hat{\omega} v$ of the human being - which, notably,

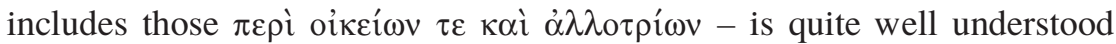
in light of this doctrine. Pohlenz therefore concluded that ethical preconceptions were held by the Stoics to form a special category of conception since they arise as a result of an innate predisposition of the human animal rather than from empirical experience alone.

Curiously, however, Pohlenz did not offer an explicit response to Sandbach's contrary account of their origin..$^{48}$ Sandbach, consequently, remained unconvinced by what he characterized as Pohlenz's "kind of a compromise" between Bonhöffer's position and his own:

I see no reason why this account should not have been welcomed by a Stoic, but

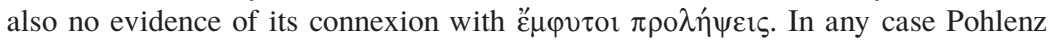
makes no claim that it is relevant to the way in which the concept of 'just' is formed. ${ }^{49}$

In fact, as noted earlier, it has been Sandbach's work that has largely carried the day in subsequent interpretation, while Pohlenz's Grundfragen has all but dropped from the discussion. In what follows, therefore, I shall reexamine the evidence with a view to the respective theses of Sandbach and Pohlenz. Is there in fact no evidence for a connection between oikeiôsis and "implanted preconceptions"? Is oikeiôsis in any way relevant to the formation of the concept of "something just"? Or does Sandbach's own reconstruction account for the evidence in a more compelling way?

${ }^{47}$ Cf. Pohlenz, Grundfragen, p. 90: "Die Oikeiosis bewirkt also, daß das Lebewesen die Außendinge nicht nur objektiv wahrnimmt, sondern zu seinem eigenen Ich in Beziehung setzt und subjektiv als nützlich oder schädlich wertet. Den Wertmaßstab liefert unsre eigene Natur und das, was ihr gemäß ist und sie fördert."

48 Pohlenz interacts explicitly with Sandbach only when rejecting Bonhöffer's claims regarding the simple identification of preconceptions with common conceptions and their limitation to matters of ethics and theology (Grundfragen, 85 and n. 1).

49 Sandbach, "ENNOIA," 34, alluding to Diog. L. 7.53; cf. idem, The Stoics (2d ed.; Indianapolis/Cambridge: Hackett, 1989) 90, which is however somewhat ambiguous in its brevity. 


\section{III}

The central importance of oikeiôsis to the philosophy of Chrysippus is clear from Plutarch's complaint that "in every book of physics, yes and of morals too," Chrysippus writes "ad nauseam that from the moment of birth we have a natural congeniality [oikeเov́ $\mu \varepsilon \theta \alpha$ ] to ourselves, to our members, and to our own offspring." 50 The crucial role of this doctrine to Stoic ethics in particular is widely recognized. ${ }^{51}$ One source that makes its importance in this respect quite clear is the summary of Stoic ethics in the third book of Cicero's On Ends. Within this account occurs the discussion of the formation of the concept of the good by means of analogy that Sandbach cited as decisive evidence against any innate origin. It is with this passage, therefore, that I shall begin.

It is important first of all to bear in mind the broader philosophical context in which On Ends 3 was written, namely, that of a sharp disagreement regarding the question of the nature of the Goal, or Highest Good. ${ }^{52}$ The Stoic representative of book three, Cato, rejects the Platonist and Peripatetic view that physical advantages like health, strength, etc., contribute anything toward the Goal, and for this reason disallows the classification of such things as "good" at all. ${ }^{53}$ Thus, for example, his treatment of health: "We deem health to be deserving of a certain value but

${ }^{50}$ Plutarch, St. Rep. 1038B; trans. after Cherniss (LCL).

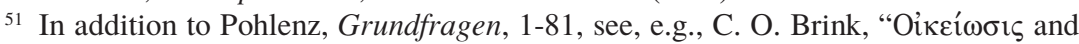

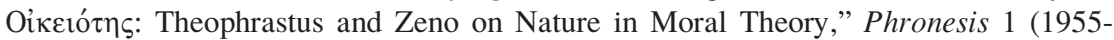
56) 123-45; S. G. Pembroke, "Oikeiôsis," in A. A. Long, Problems in Stoicism, 11449; A. A. Long, "The Logical Basis of Stoic Ethics," Proceedings of the Aristotelian Society 71 (1970/71) 85-104; Inwood, Ethics and Human Action, 182-201, esp. 194; Long and Sedley, The Hellenistic Philosophers, 1. 350-54; Troels Engberg-Pedersen, The Stoic Theory of Oikeiosis: Moral Development and Social Interaction in Early Stoic Philosophy (Studies in Hellenistic Civilization 2; Denmark: Aarhus University Press, 1990); cf. idem, Paul and the Stoics (Louisville: Westminster/John Knox, 2000) 45-79. Gisela Striker suggests that oikeiossis "was probably not the foundation of Stoic ethics," but considers its importance in this system to be "obvious" nonetheless; see "The role of oikeiôsis in Stoic ethics," in Julia Annas, ed., Oxford Studies in Ancient Philosophy 1 (1983) 145-67; repr. in Gisela Striker, Essays on Hellenistic Epistemology and Ethics (Cambridge: Cambridge University Press, 1996) 281-297, here 295.

52 The work as a whole, of course, presents in turn, and with subsequent critiques, the positions of the Epicureans, Stoics, and Antiochus of Ascalon on the matter; cf. esp. the summary of the positions in 5.15-23.

53 Fin. 3.41-48. 
we do not place it among the goods." ${ }^{54}$ The Highest Good, which is to say virtue or honestum, is in fact the sole good in this system. ${ }^{55}$ In effect, the Stoic Cato makes a technical distinction between bonum, or the Good in the strict Stoic sense as virtue alone, and aestimabile, or "the valuable," under which fall those physical advantages classified as "good" by the Platonists, Peripatetics, and more generally in common parlance. This distinction is scrupulously observed throughout Cato's summary, and will in fact provide one of the chief points of Cicero's subsequent critique. ${ }^{56}$

Secondly, with this technical distinction in mind, we must understand Fin. 3.33, the specific passage to which Sandbach referred, in the context of the larger account of the development of the notion of the Good presented in book three. In 3.20-22, Cato explains that the concept of what Stoics call "the good" develops later than that of "the valuable," which they consider the prima divisio. Formed in tandem with its opposite (inaestimabile), "the valuable" represents a conceptualization of the more general distinction between things in accordance with one's nature, and thus "deserving of choice," and things that are not. According to the Stoics the practical drawing of this distinction is of course guaranteed on the part of all animals, immediately from birth, by oikeiossis - an account of which, therefore, opens Cato's exposition..$^{57}$ The formation of the concept of "the valuable," in other words, is the inevitable result of (i) the innate tendency of all animals to distinguish what is beneficial to their constitutions from what is harmful; and (ii) the human animal's possession of reason, the natural tendency of which is to organize experience into concepts.

The recognition, on the other hand, of "that which can truly be said to be good" (quod vere bonum possit dici) - as opposed to that which the Stoic merely considers "valuable" - is a subsequent development:

Man's first attraction is towards the things in accordance with nature; but as soon as he has understanding [intelligentiam], or rather becomes capable of 'conception' [notionem] - in Stoic phraseology évvoi $\alpha$ - and has discerned the order and so to speak harmony that governs conduct, he thereupon esteems this harmony far more highly than all the things for which he originally felt an affection, and

${ }^{54}$ Fin. 3.44: nam qui valetudinem aestimatione aliqua dignam iudicamus neque eam tamen in bonis ponimus.

55 E.g. Fin. 3.21, where Cato speaks of honestum, quod solum in bonis ducitur.

56 E.g. Fin. 4.56-61. Cicero here takes the Antiochean view (apparently originally espoused by Carneades; see 3.41) that the Stoics differ on this issue from the Peripatetics and Platonists in terminology, but not in substance; cf. 4.3-5 and 21-23.

${ }^{57}$ Fin. 3.16-19. 
by exercise of intelligence and reason infers the conclusion [cognitione et ratione collegit] that herein resides the Chief Good of man, the thing that is praiseworthy and desirable for its own sake. ${ }^{58}$

It is striking that Cicero's Cato correlates the development of the concept of "the good" with the ability to form हैvvotat. This term can only be interpreted in its strict sense here. The formation of the concept of "the valuable," according to Cato's scheme, had already occurred well prior to the formation of that of "the good"; the stipulation that the latter can be arrived at only with the ability to form Évvorar would thus make little sense if he simply meant the general tendency of the rational animal to form concepts from experience. Cicero's Cato, moreover, associates the ability to form Évvotal with the possession of intelligentia, which, as is clear from the context, is characterized by a capacity for rational examination and inquiry. The formation of concepts by such intellectual means is the mark of "Evotal in the strict sense, not preconception.

We are now in a position to evaluate properly Cicero's account of the formation of the concept "good" by analogy that is so central to Sandbach's argument. The characterization of this concept as having arisen by means of "analogy" (collatione rationis) "from the things in accordance with nature" is to be interpreted in light of the fuller account offered in 3.20-21. The notitia boni that is at issue here arises by analogy from what the Stoics consider "the valuable." It does not result from simple mental processes that occur automatically already in the pre-rational stages of early childhood. On the contrary, the analogical thought required for the formation of this concept is only possible for one with a properly rational mind and an ability to form हैvvor $\alpha$ in the strict sense. Despite Sandbach's objections, then, Bonhöffer's contention that 3.33 referred not to an illdefined preconception of "something good" (cf. Diog. L. 7.53) but to an Évvor $\alpha$ in the strict sense turns out to have been quite to the point. Cato's concern in this particular passage, indeed, is not how humans come to formulate general ethical distinctions between "good" and "bad," but the manner in which one arrives at the concept of the good properly so-called, i.e., of that which the Stoic considers good. The passage, in short, does not concern the origin of a preconception.

${ }^{58}$ Fin. 3.20-21; trans. after Rackham (LCL). Though Cato speaks of the summum bonum at the end of this passage, this is in fact the only "good" in his system. Honestum, he continues, is "that Good which is the End to which all else is a means" and thus "alone is counted among the goods" (quod solum in bonis ducitur). 
The preconception of the good is not discussed, at least as such, by Cato. He begins to use the term "good" only in connection with the ability to form "ैvvor $\alpha$, speaking strictly of the "valuable" prior to that. The Stoics, however, would hardly have denied that very young children already meaningfully use the general terms "good" and "bad" to describe that which the Stoics considered only "valuable." Cato's avoidance of the term "good" at this early stage is the result of the technical distinction drawn by Stoics between "good" and "valuable." He is in any case quite explicit that the concept of what is truly good develops directly from the concept of the valuable. In order to understand the ultimate origin of the concept of former, then, one must inquire after the origin of the latter; and this, it is clear, is the result of an innate disposition to distinguish things beneficial to one's nature from things not beneficial that characterizes all animals owing to oikeiôsis.

Examination of Seneca's Epistle 120, the other principal text cited by Sandbach in this connection, yields quite similar results. The question addressed in this letter is "how a conception of the good and the honorable first comes to us," ${ }^{59}$ and Seneca also reports that it occurs per analogian (120.4). Like Cicero's Cato, however, Seneca's concern here is the concept of the Good in the limited, Stoic sense of the term. This becomes clear immediately as he opens the letter by clarifying the Stoics' peculiar position regarding the term bonum. While some, he scoffs, define it as that which is advantageous (utile) and thus apply it to such base things as horses or shoes, for the Stoics "nothing is good except that which is honorable." ${ }^{60}$ It is therefore no surprise when he goes on to equate the notitia boni honestique with a "notion of virtue" (virtutis speciem) in 120.4. Informing the whole of this letter, then, is a distinction between the general term "good" as used by others - for which Seneca will use the term "advantageous" (utile; cf. Cicero's aestimabile) - and the Good in the proper (Stoic) sense.

When Seneca goes on to identify analogy as the means by which one acquires a concept of the good and honorable, then, it is clear that he has this latter sense of the term in mind rather than the manner in which one first acquires a preconception of the good, i.e., the ultimate origin of the human tendency to distinguish between "good" and "bad" in the most general sense. As in On Ends 3, in fact, one arrives at the notion of the Good

${ }^{59}$ Ep. 120.1: quomodo ad nos boni honestique notitia pervenerit; cf. 120.3 .

${ }^{60}$ Ep. 120.1-3: nihil est bonum nisi quod honestum est. Conversely, quod honestum est utique bonum. 
by analogy from bodily advantages like health and strength. ${ }^{61}$ Formation of the particular concept that is of interest to Seneca here, in other words, presumes that one has already acquired the concept that he calls "advantageous," but which others would simply call "good." Seneca does not pursue the origin of this latter, more general conceptual distinction in any detail. He does, however, insist that Nature itself guarantees that a notion of virtue will be formed by providing "seeds of knowledge" of the Good:

Nature could not teach us this [viz., the boni honestique notitia] directly; she has given us the seeds of knowledge, but not knowledge itself [semina nobis scientiae dedit, scientiam non dedit]. Some say that we merely happened upon this knowledge; but it is unbelievable that a vision of virtue could have presented itself to anyone by mere chance. ${ }^{62}$

As noted above, Sandbach interpreted these "seeds" as a reference to "the facts observed" from which, apparently, the analogy to the Good is made. ${ }^{63}$ In Epistle 121, however, Seneca explicitly distinguishes between knowledge gained by empirical experience, which is "slow and irregular," and that communicated directly by Nature, which "belongs equally to everyone, and comes immediately." ${ }^{44}$ This latter knowledge, moreover, is nothing other than that guaranteed by oikeiôsis:

Nature has communicated nothing except the duty of taking care of themselves and the skill to do so ... No wonder that living things are born with a gift whose absence would make birth useless. This is the first equipment that Nature granted them for the maintenance of their existence - the quality of adaptability and selflove. ${ }^{65}$

Seneca, in fact, is quite explicit in clarifying that such tendencies are not ingrafted, but inborn (nec inseritur sed innascitur); thus are they said to arise not from experience (non usu) but naturally (naturali). ${ }^{66}$

In light of this analysis, Sandbach's argument against any innate dimension to the Stoic understanding of ethical concepts is scarcely compelling.

61 Ep. 120.5 .

${ }^{62}$ Ep. 120.4; trans. after Gummere (LCL). Cf. Ep. 108.8: omnibus enim natura fundamenta dedit semenque virtutum.

${ }^{63}$ Sandbach, "ENNOIA," 36 n. 23.

${ }^{64}$ Seneca, Ep. 121.20: et tardum est et varium, quod usus docet; quicquid natura tradit, et aequale omnibus est et statim.

${ }^{65}$ Ibid.; cf. Ep. 121.23. Note further that Seneca characterizes the initial stage of this natural self-understanding in terms reminiscent of preconceptions: one's constitution is initially understood crasse... et summatim et obscure.

${ }^{66}$ Ep. 121.17, 20. 
What is of concern in both passages is not the ultimate origin of the preconception "good," but the process by which this more general notion which the Stoics, given their peculiar stand on the telos, designate "useful" or "advantageous" rather than "good" - comes to be applied in its proper (Stoic) sense to virtue. This occurs only when one has acquired the ability to form Évvoral in the strict sense, when one has reached the age of reason - at which time, after all, a virtuous disposition first becomes possible at all. ${ }^{67}$ Both Cicero and Seneca, moreover, trace the ultimate origin of the general human tendency to make ethical distinctions to the rational animal's innate sense of self-awareness and self-concern. The formation of preconceptions of "good" and "bad," in other words, is guaranteed by oikeiôsis.

The Stoics, then, understood ethical preconceptions to be a unique category of preconception inasmuch as they arise as the result of an innate evaluative disposition that every animal brings to its empirical experience. ${ }^{68}$ These preconceptions can thus be said to arise "naturally" in an even more specialized sense than other preconceptions. Once this is recognized, the loose ends remaining in Sandbach's reconstruction tie up quite nicely. The reason Diogenes Laertius speaks of the concept of "something just and good" (rather than simply "the Good") as arising naturally is that he is concerned with the formulation of ethical categories in general, which form "naturally" due to oikeiôsis. From the Stoic point of view, the concept Good properly so-called represents a later development, formed by analogy from the preconception of things appropriate to one's (pre-rational) constitution. Further, the point of Plutarch's comment in Comm. not. 1070C, which Sandbach struggled to make sense of, becomes perfectly clear. The distinction drawn by Plutarch between concepts of opposing pairs that arise within a person, like good/bad, desirable/repugnant or congenial (oikعîs!)/alien, and those that arise "from outside" due

67 Seneca's Epistle 121, once again, is illuminating in this connection. In 121.1416 Seneca replies to an imagined interlocutor who raises this objection: If the Stoics argue that every living thing is adapted to its own constitution from birth, and humans are rational animals, "how, then, can a child, being not yet gifted with reason, adapt himself to a reasoning constitution?" Seneca counters by saying that "each age has its own constitution," whether infancy, boyhood, youth, or adult; "the child," then, "is adapted to that constitution which is his at the present moment" - and which is not yet the "higher phase into which he must be changed."

${ }^{68}$ Cf. Pohlenz, Grundfragen, 92: "Die Empirie ist dabei unentbehrlich, aber die primäre Ursache liegt in der Natur des $\lambda$ o der sittlichen Begriffe enthalten ist." 
to empirical experience, like cold/warm or white/black, is simply that between concepts resulting from oikeiôsis and those that do not. The former are rooted in the very nature of the rational animal itself, and their formation is thus guaranteed regardless of one's particular experiences; the same cannot be said of the latter. Finally, one need not resort to suggestions of "temporary aberration" in the writings of Chrysippus to explain

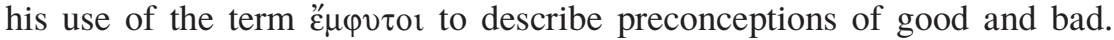

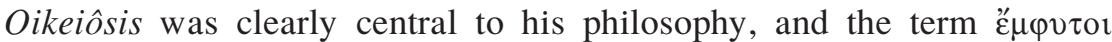

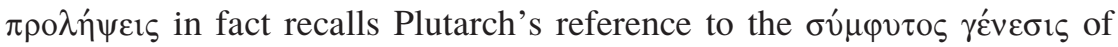
concepts guaranteed by oikeiôsis.

It should be emphasized, finally, that there is no contradiction between the theory of implanted preconceptions outlined here and the Stoic characterization of the commanding faculty, at birth, as a tabula rasa. The human individual is not born with ethical conceptions per se, only with an innate predisposition to form these concepts owing to oikeiôsis. ${ }^{69}$ Indeed, the practical ability to recognize, generally speaking, "something good" or "something bad" with respect to one's constitution is not limited to the rational animal, but is characteristic of all animals regardless of their ability to abstract from experience formal concepts of "good" and "bad." Nature, as Seneca puts it, implants the "seeds" of this knowledge within the rational animal, but does not give knowledge itself (Ep. 120.4).

The link between oikeiôsis and ethical concepts suggested by these passages from Plutarch, Cicero and Seneca, then, well clarifies both Chrysippus'

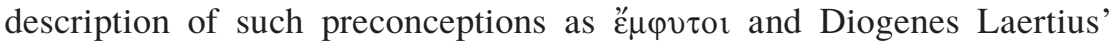
comments about the natural formation of the concept of something good. What, however, of the concept of "something just," which is also singled out by the latter author as naturally arising? The details of the Stoic treatment of the origin of justice are notoriously difficult to reconstruct, and an adequate treatment of the problems is not possible in the present context. ${ }^{70}$ What is clear in any case is that the Stoics traced the ultimate origins of justice precisely to oikeiôsis. "The followers of Zeno," Porphyry

${ }^{69}$ Cf. Pohlenz, Grundfragen, 92: "Bei der Geburt sind die Begriffe freilich noch nicht vorhanden. Die Seele gleicht der tabula rasa, und es gibt in ihr keine Begriffe, weder fertige noch unfertige. Angeboren ist aber dem Lebewesen nach seiner seelischen Struktur durch die Oikeiosis die Tendenz und die Fähigkeit, zu den Dingen wie zu sich selbst wertend Stellung zu nehmen."

70 See on this question esp. Engberg-Pedersen, The Stoic Theory of Oikeiosis, 12226; idem, Paul and the Stoics, 66-70; Inwood, "Comments on Professor Görgemanns' Paper: The Two Forms of Oikeiôseis in Arius and the Stoa," in William W. Fortenbaugh, On Stoic and Peripatetic Ethics: The Work of Arius Didymus (New Brunswick 
says quite explicitly, "make oikeiôsis the beginning of justice."71 Though the details are obscure, it is most probable that the Stoics placed the natural affection of parents for their offspring - an affection that was said to be providentially guaranteed by oikeiôsis - at the center of their account of justice. Chrysippus, in fact, is known to have argued that "even the beasts have been endowed with congeniality to their offspring in proportion to need" precisely in the first book of his On Justice. ${ }^{72}$ It is not insignificant, therefore, that Cicero describes this parental affection, too, as being "implanted" by Nature. ${ }^{73}$

\section{IV}

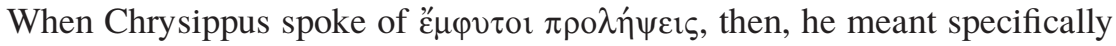
those preconceptions whose formation was guaranteed by oikeiôsis, namely preconceptions in the sphere of ethics. These preconceptions result not simply from empirical experience, but ultimately from an innate disposition that the rational animal - like all animals, according to the Stoics brings to its empirical experiences. The question that remains is why later Stoics, at least, began to speak of belief in gods in the same way.

Such usage is assumed to be appropriately Stoic by both Seneca and Cicero. Seneca, explaining the Stoic understanding of arguments from consensus, remarks in passing that they deduce the existence of the gods not least "because a belief about gods is implanted in everyone." " Balbus, the Stoic spokesperson of Cicero's On the Nature of the Gods, similarly claims that all peoples agree on the existence of the gods due to the fact that such a belief "is innate in everyone, and as if engraved in the mind." "75

and London; Transaction, 1983) 190-99; Pembroke, "Oikeiôsis," 121-32; Striker, "The role of oikeiôsis," 282, 293-95.

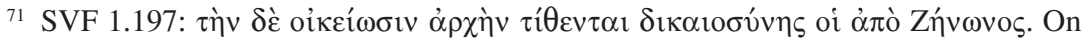
"the followers of Zeno" here, see Pembroke, "Oikeiôsis," 122.

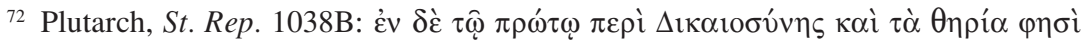

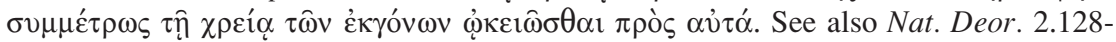
29 and Fin. 3.62, and further on this point below.

73 Off. 1.12: natura . . . ingeneratque in primis praecipuum quendam amorem in eos, qui procreati sunt. Cicero speaks here of the human animal in particular, whose affection for its offspring, however, differs only in degree from that of other animal species; cf. Off. 1.11. See further Fin. 5.66.

${ }^{74}$ Ep. 117.6: quod omnibus insita de dis opinio est.

${ }^{75}$ Nat. Deor. 2.12: omnibus enim innatum est et in animo quasi insculptum esse deos; cf. 1.44, where the view is also associated with the Epicureans. On the general importance of the Epicurean treatment of preconception to the Stoics, see Malcolm 
Unfortunately, however, neither passage provides any theoretical basis for including belief in gods among the implanted preconceptions.

Cicero, however, does elaborate a bit more fully on the idea in his $O n$ Laws. Here it is explained that all humans - and humans alone - have a notitia dei due to the unique kinship (agnatio) that humans have with the gods. The kinship Cicero has in mind here is based on the human possession of a rational soul - which, unlike the "fragile and perishable" elements of the human animal derived from the mortal sphere, was implanted by God. ${ }^{76}$ Reason is thus crucial for the formation of the notitia dei, and not simply because it is requisite for concept formation in general. Possession of reason necessarily entails recognition of a god, because each person "as it were, remembers and recognizes" the source from which (s)he came. ${ }^{77}$ This reference to memory, however, has a curiously Platonist ring to it. The dualism of body and soul underlying the explanation, moreover, is more reminiscent of Antiochus of Ascalon - who, in fact, is likely the principal source for Cicero's On Laws - than any proper Stoic. ${ }^{78} \mathrm{We}$ would seem in this case, then, to be dealing with precisely the kind of synthesis of Stoic and Platonist thought that Sandbach and others suggested regarding the implanted preconceptions more generally. ${ }^{79}$

Schofield, "Preconception, Argument and God," in Malcolm Schofield et al., eds., Doubt and Dogmatism: Studies in Hellenistic Epistemology (Oxford: Oxford University Press, 1980) 283-308, esp. 291-98.

${ }^{76}$ Leg. 1.24: animum esse ingeneratum a deo. That Cicero has in mind here specifically the rational soul seems clear from the fact humans are held to be unique among other mortal animals owing to its possession of reason, not soul - which latter, on the contrary, characterizes all animals by definition; cf. 1.23.

77 Leg. 1.25: qui unde ortus sit quasi recordetur et agnocat. Cf. Pohlenz's interpretation: "Auch die Gotteserkenntnis wurzelt also in der Struktur unsrer Physis" (Grundfragen, 100).

78 A strikingly similar version of body-soul dualism underlies much of Arius Didymus' discussion of oikeiosis, where the human animal is said to be "distinguished in body and soul from other living beings, since he is in between immortal and mortal things, and has bonds of community with both, with the rational beings by the divine element in his soul, with the irrational beings by the mortal element in his body" (2.1). For translation and discussion of the relevant passage see H. Görgemanns, "Oikeiôsis in Arius Didymus," in Fortenbaugh, On Stoic and Peripatetic Ethics, 165-89. Inwood argues convincingly that this aspect of Arius' treatment is Antiochean in origin ("Comments," 192-93). On the source of Cicero's On Laws see L. P. Kenter, M. Tullius Cicero, De Legibus: A Commentary on Book I (trans. J. L. Leenheer-Braid; Amsterdam: Adolf M. Hakkert, 1972) 9-10; on Antiochus in particular as source see most recently Paul A. Vander Waerdt, "The Stoic Theory of Natural Law" (Ph.D. diss., Princeton University, 1989).

79 So, e.g., Kenter, De Legibus, 105. 
On the other hand, Cicero's recourse to "kinship" in this connection finds an interesting correspondence in Dio Chrysostom's Olympic Discourse, the fullest extant account of the issue, and one more congenial to Stoicism. Dio distinguishes two sources of people's belief in the deity: the laws, stories and arts produced and handed down within a given society; and "the notion implanted in all human beings," which he identifies as the ultimate origin of this universal human belief. ${ }^{80}$ The implanted notion is itself

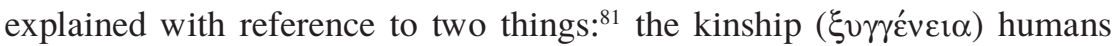
have with gods, and the "many witnesses to the truth," such as the order of creation and the many benefits bestowed upon human beings (12.2832). The latter point immediately raises a question about the role of empirical experience here, and thus the relationship between this "implanted" concept and those posited by Chrysippus. Before this crucial issue is addressed, however, the significance of kinship in this connection must be clarified.

It is to be noted at the outset that Dio makes no reference to an immortal substance shared by humans and gods that gives rise to a "memory" of one's ultimate, divine source. The key to Dio's interest in kinship is rather his notion that people's experience of their human parents is paralleled by an experience of the divine parent:

... the feelings of the human race towards their first and immortal parent, whom we who have a share in the heritage of Hellas call Fatherly Zeus, develop step by step along with those which men have toward their mortal and human parents. For in truth the goodwill and desire to serve which the offspring feel toward their parents is ... present in them, untaught, as a gift of nature and as a result of acts of kindness received, since that which has been begotten straightaway from birth loves and cherishes in return, so far as it may, that which begat and

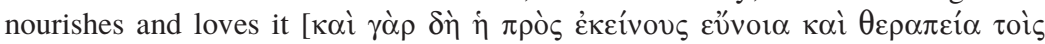

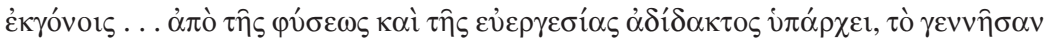

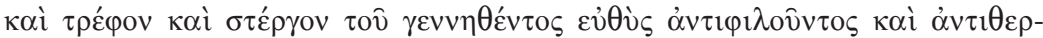

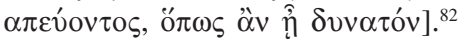

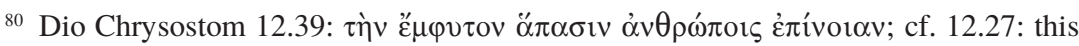
"implanted" notion "comes about naturally without mortal teacher and mystagogue,

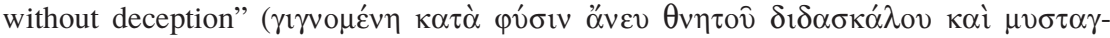

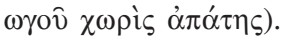

${ }^{81}$ Dio Chrysostom 12.27, reading $\delta$ í rather than $\varepsilon \delta \dot{\eta} \lambda$ ov with, most recently, Hans-Josef Klauck, Dion von Prusa: Olympische Rede oder über die erste Erkenntnis Gottes. Eingeleitet, übersetzt und interpretiert (Darmstadt: Wissenschaftliche Buchgesellschaft, 2000) 62, 124 n. 134.

${ }^{82}$ Dio Chrysostom 12.42; trans. after Cohoon (LCL), with the exception of his rendering of $\pi \alpha \tau \rho \hat{o}$ ov $\Delta i \dot{i} \alpha$ as "Ancestral Zeus." While this translation is a more accurate 
As noted above, this parent-child relationship figured importantly in Chrysippus' understanding of oikeiôsis, as is clear from Plutarch's complaint that he relentlessly emphasized the congeniality one has from birth to oneself and to one's offspring. Plutarch goes on to note that Chrysippus, in the first book of his On Justice, argued that "even the beasts have been endowed with congeniality for their offspring in proportion to its need, except in the case of fishes, for their spawn is nourished of itself." ${ }^{83}$ Plutarch's wording, however, seems to imply that Chrysippus argued only that a parent's love for its offspring was guaranteed by oikeiôsis - not the reverse. If this is the case, he (and subsequent Stoics) were left in the rather awkward position of arguing that one's affection for one's offspring is present immediately from one's own birth. Brad Inwood has thus argued persuasively that personal and social oikeiôseis were not well integrated in the philosophy of Chrysippus. "The social oikeiôsis was a later graft [from Aristotle] onto the Stoic doctrine of personal oikeiôsis . . . the Stoics themselves had only an ad hoc explanation for the relation of the two oikeiôseis ..." ${ }^{84}$

Dio's understanding of social oikeiôsis addresses this crucial gap by emphasizing precisely that the child's affection for its parent is "untaught," is "from nature." While Dio, to be sure, cites the parents" kindness toward the child as being a crucial factor here, his language suggests that the whole reciprocal relationship is guaranteed by nature. One might compare here the comments of Cicero's Stoic spokesman Balbus on mammals in general. Balbus finds, if not necessarily reciprocal affection, at least a mutual proclivity of mother for child and child for mother guaranteed by nature in such animals. Mammalian mothers, he observes, begin producing milk for their child after birth, while the newborn, "untaught and by nature's guidance" seeks its mother's breast. ${ }^{85}$ While the mother is natu-

rendering of what the title normally means, it fails to bring out Dio's main interest in it in this context. "Dion hat $\pi \alpha \tau \rho \hat{o} \circ \varsigma$, bezogen auf Zeus, aber eher im Sinn des homerischen Epithetons 'Vater der Götter und Menschen' verstanden”; so Klauck, Dion von Prusa, 133 n. 211, after whose "väterlichen Zeus" I have modeled the rather less elegant "Fatherly Zeus."

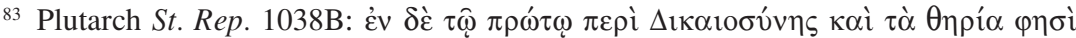

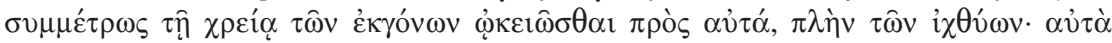

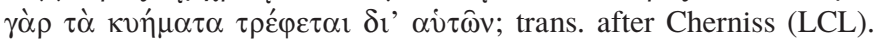

${ }^{84}$ Inwood, "Comments," 193-99, here 199.

${ }^{85}$ Nat. Deor. 2.128: quod cum ex utero elapsum excidit, in iis animantibus quae lacte aluntur omnis fere cibus matrum lactescere incipit, eaque quae paulo ante nata sunt sine magistro duce natura mammas appetunt earumque ubertate saturantur. 
rally disposed to nourish its child, in other words, the child for its part has an innate tendency to seek out its mother. Dio's point would seem to be that the universal human belief in - and in fact affection for - the deity is the result of an analogous dynamic. The first "breast" one encounters is that of Mother Earth, whose air - "more fluid than milk" - provides one's first nourishment, breathing life into the newborn. Belief in - and indeed admiration and love for - the "first and immortal parent" who created and now nourishes them is thus, for Dio, as natural and inevitable as one's knowledge of and affection for one's human parents (12.29-32).

This account greatly illuminates the pairing of kinship and empirical experience in Dio's explanation of the origin of the implanted notion of the deity. Humans, he assumes, have an innate tendency toward sociality with their parents (or at the very least their mothers), even as parents have an innate affection for their offspring according to Chrysippus' theory of oikeiôsis. Once again, however, this inborn tendency is linked inextricably to empirical experience, for it represents precisely a natural disposition to evaluate that experience subjectively. ${ }^{86}$ Empirical experience is thus crucial for the actual formation of the concept of deity as understood by Dio, just as it is crucial for concept formation in general according to the Stoics. This concept, like Chrysippus' implanted preconceptions, is however different inasmuch as its formation is guaranteed by oikeiôsis; it has in this sense been "implanted," if only in inchoate form, by nature. Humans, according to Dio, are born with a natural sociality toward parents, and the experience of nature's nurture leads inevitably to the formation of a concept of - and love and admiration for - an immortal parent, the deity.

An evaluation of the extent to which Dio's account provides a satisfactory solution to the problem of social oikeiôsis that Chrysippus apparently bequeathed to his followers would require a discussion that would take us too far afield from our present concern. Whatever its philosophical merits, the salient point for our purpose is that Dio's account of the implanted concept of the deity leads us back, once again, to oikeiôsis.

The fact that one first finds the concept of the deity described this way in sources of the Roman era suggests that it was a later development in Stoicism - perhaps a by-product of later Stoic attempts to bridge an

${ }^{86}$ Cf. Plutarch's recognition of the close relationship between oikeiôsis and sensation, found immediately after his complaint regarding Chrysippus' tiresome belabor-

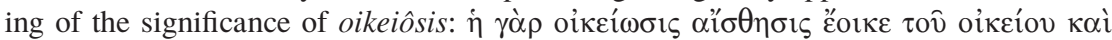

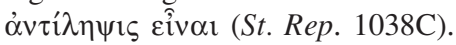


embarrassing gap between personal and social oikeiôsis. This would seem to be confirmed by the fact that the argument for an innate concept of god plays a quite marginal role in Cicero's summary of Stoic theology. The idea is mentioned only once, in passing, in a summary statement in Nat. Deor. 2.12. It does not surface again in his discussion of the Stoic arguments regarding the existence of the gods, let alone in his summary of the specific arguments of Zeno, Cleanthes, or Chrysippus; nor is it brought up in the Academic critique of Stoic theology offered in book three. If a later development, however, it was not, at least in this form, simply the result of Stoic-Platonist "syncretism." The attempt was made - however successfully - to defend this argument from genuinely Stoic foundations. Like the "implanted preconceptions" posited by Chrysippus, the universal formation of this concept was explained with reference to oikeiôsis.

\section{V}

Chrysippus distinguished two types of concepts. Concepts ("̌vvol $\alpha$ ) in the strict sense of the term are the result of conscious intellectual effort and begin to be formed only when one has achieved an initial state of rational maturity. Preconceptions ( $\pi \rho \circ \lambda \eta \dot{\psi} \psi(\varsigma)$ occur "naturally," that is, they result from simple mental processes that do not require conscious intellectual labor, and begin to form already in the earliest stages of childhood. While empirical experience was understood to be necessary for the formation of all concepts, fundamental ethical concepts such as "good" and "bad" form a special class of preconception, called implanted preconceptions (" in all animals, to evaluate experience subjectively, distinguishing what is beneficial for themselves from what is harmful. Humans are not born with ethical conceptions per se; nonetheless, as rational animals in whom concepts naturally begin to form almost immediately, they are predisposed to the formation of these conceptions regardless of the nature of their experiences.

While the notion that the concept of the deity was similarly "innate" seems to have been a later development in Stoic theology, Epictetus' view that humans are born "as if already taught by nature certain things" in the realm of ethics thus seems to be basically consistent with Chrysippus' own

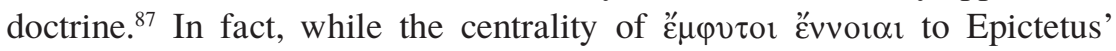

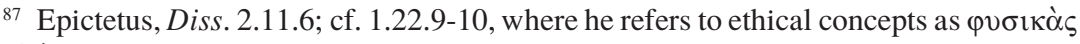
$\pi \rho \circ \lambda \dot{\psi} \psi \varepsilon \iota \varsigma$, i.e., natural concepts of an especially natural variety. 
ethical philosophy goes beyond anything explicitly attested in our scant evidence for Chrysippus, it is nonetheless tempting to suggest that here, too, Epictetus is something less than a maverick. If Inwood's reconstruction of the early Stoic psychology of action is generally correct, it is easy to imagine that proper application of the concept of good would have been every bit as central for Chrysippus as it was for Epictetus. According to Inwood, the early Stoics understood human action to be caused by the impulse resulting from assent to the propositional content of a hormetic presentation. ${ }^{88}$ For example, a man's acceptance of some public office will depend upon his assent to the proposition "it is good for me to accept this office." Such assent will obviously presuppose some conception of what is good and what is not, on the basis of which the man will either give or withhold his assent to the proposition. If his conception of the good is incorrect, his assent to the proposition may well (though not necessarily) result in an impulse toward improper action. If this is correct, the only way to ensure consistent virtuous action would seem to be possession of an accurate conception of the Good. It is not surprising, therefore, to find Diogenes Laertius grouping a substantial body of Chrysippus' ethical trea-

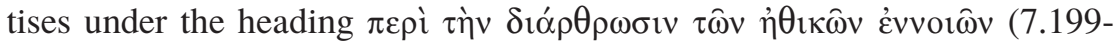
200). ${ }^{89}$ Nor is it difficult to imagine Chrysippus sharing Epictetus' own central preoccupation: "Where, then, shall we place the good? To what sort of things shall we apply it?"90

\section{Niagara University}

88 Inwood, Ethics and Human Action, esp. ch. 3.

${ }^{89} \delta i \alpha \rho \theta \rho \omega \sigma \iota \varsigma$, or the refinement and systematization of (especially ethical) preconceptions is a central concept for Epictetus; see, e.g., Diss. 2.17; further Bonhöffer, Epictet und die Stoa, 189-92.

${ }^{90}$ Diss. 1.22.11; cf. further, e.g., 2.11; 2.17; also 4.1.41-44. 